\title{
Health Deprivation in Rural Settlements of Borno State, Nigeria
}

\author{
A. Adedayo ${ }^{1} \&$ R. O. Yusuf ${ }^{2}$ \\ ${ }^{1}$ Department of Geography, University of Ilorin, Ilorin, Nigeria \\ ${ }^{2}$ Department of Geography, Ahmadu Bello University, Zaria, Nigeria \\ Correspondence: R. O. Yusuf, Department of Geography, Ahmadu Bello University, Zaria, Nigeria. Tel: \\ 234-802-349-6588. E-mail: royusoba@yahoo.co.uk
}

Received: March 1, 2012 Accepted: March 14, 2012 Online Published: September 20, 2012

doi:10.5539/jgg.v4n4p52 URL: http://dx.doi.org/10.5539/jgg.v4n4p52

\begin{abstract}
Illness and burden of diseases are manifestation of health deprivation. In rural areas, most of the diseases afflicting people are in most cases outcomes of failure of public health policy and ecological incapacity. This paper addresses these issues using Borno state as the setting. The objectives of the paper are to delineate the spatial pattern of health deprivation, and identify the coping strategies for mitigating health deprivation. Data were gathered through primary (Questionnaire administration and participatory rural appraisal techniques) and secondary (Policy documents on health, water and environment) sources. A multistage sampling approach was used to select respondents from the two ecological zones in the study area out of which 630 respondents were selected from 9 local government areas. Data were analyzed through descriptive statistics and Z-score analysis. Among the findings is that about $83 \%$ of the sampled rural respondents spent between 1-2 hours to reach medical facility. Due to cost and distance to health facility about $65.26 \%$ claimed to experience deprivation. The major ailments reported include flu, malaria and typhoid fever, cerebrospinal meningitis, scabies and physiological discomfort. Spatially rural areas with health facility and clement weather conditions have low Z-score (Damboa (-5.94), Hawul (-2.24) and Konduga (-2.01) while highly deprived are settlements in Kukawa (5.11), Monguno (2.68) Kwaya-Kusar (1.26) and Mobbar (1.15).The coping strategies adopted include Praying to God; use of alternative medicine; patronizing 'Chemists' and migration. The conclusion is that spatial disparity in health deprivation should be addressed to improve the quality of life among rural dwellers. Recommendations include advocating self-help approach to health infrastructure provision, promotion of rain water harvesting technology and involving non-government organizations in rural health issues.
\end{abstract}

Keywords: health deprivation, rural settlements, ecological incapacity, policy failure, participatory rural appraisal, Borno state

\section{Introduction}

Illness and burden of diseases are manifestation of health deprivation. Qualitative or quantitative malnutrition and utilization of contaminated water are direct consequences of inappropriate public health policies and environmental condition which have deleterious effects on health and wellbeing at the local level. In fact, one of the ecosystem benefits to humans according to Millennium Ecosystem Assessment report (2006) is regulating ill-health and diseases.

Murphy (2005) quotes World Health Organization (WHO)'s 1978's definition of health as "a state of complete physical, psychological and social well-being and not simply the absence of disease or infirmity". Ideally, Nwaiwu and Okuoju (2004) advocated for exploring indigenous knowledge in providing for health of villagers. According to the authors "the best way to promote hygiene of the rural dwellers is to build on what they know. Village technology should not seek to bring about an immediate rural technological revolution but rather introduce practical and adaptable small initial changes" (Nwaiwu and Okuoju, 2004). Due to health service deprivation, top risk factors resulting in disease, disability or death such as underweight, unsafe sex, unsafe water, sanitation and hygiene are high in rural areas (Ademola, 1997).

Although, in Nigeria, the national average of doctor to population ratio is disproportionate, it is grossly skewed against the rural areas. As an illustration, the United Nation System's Survey (2001) on Nigeria reveals that although only $52.8 \%$ of Nigerians have access to adequate sanitation, rural-urban difference is $75.3 \%$ of urban 
and $44.4 \%$ rural. With an access rate of between 5\% and 17\%, African Development Report (2002) from African Development Bank put Nigerian rural dwellers among the most deprived Africans in terms of sanitation. Access to doctors, nurses, midwives and other orthodox health personnel in rural areas is remarkably low. This actually underscores why Adedayo (2000) advocated that Nigerian policy makers should formulate and implement sanitation policies at the local level.

Despite the pronouncement that basic health should be available, accessible, and acceptable to the local community in the WHO/UNICEF Primary healthcare Declaration in 1978, and the awareness of deprivation in health care needs of rural populace, they are yet neglected (Akpovi, 2002). Health deprivation is observed in terms of the physical distance separating rural healthcare users and nearest public health facility and the quality and price of such services (Castro-Leal et al., 1999).

Rural health problems such as Onchocerciacis are associated with some national economic policies such as large-scale agricultural projects of dam construction and irrigation activities (Nwoke et al., 1994 (cited in Omudu \& Onah, 2002)). Adedayo (2003) also reported similar case in Kazaure LGA of Jigawa State, Nigeria that socioeconomic impact of schistosomiasis manifests in declining productivity (in terms of farm income) and, well-being (in terms of negative effect of infection on farmer's personal development attributes). Health deprivation in rural areas perhaps necessitated Castro-Leal et al. (1999)'s conclusion that public health spending in African does not benefit the rural poor. Nonetheless, some rural spaces are more deprived than others, especially those at the bottom of the stratification system (Kerbo, 2000). The foregoing provides the underlying purpose and philosophy of this paper. The objectives are to delineate the spatial pattern of health deprivation and identify the coping strategies for mitigating health deprivation.

\section{Study Area}

Borno state was created in 1976 from the erstwhile north eastern state. It has an area of $69,435 \mathrm{sq} \mathrm{Km}$ and lies within Latitude $10^{\circ} \mathrm{N}$ and $13^{\circ} \mathrm{N}$ and longitude $12^{\circ}$ and $15^{\circ} \mathrm{E}$ (Ijere \& Daura, 2000; Online Nigeria, 2003a). The 2006 census put the population at 4,151,193 (Federal Republic of Nigeria Official Gazette, 2007).

There are twenty-seven Local Government Areas (LGAs) divided ecologically into Borno north and south. In terms of relief, two relief regions: the Chad plains and the highlands of the Biu plateau and Mandara Mountains are identified (Ijere, 1993). The drainage is characterized by two major groups of rivers. Rivers Yobe and Yedseram in the north drain into the Lake Chad while, rivers Hawul, Shanni, etc in the south drain into the Benue system (Ijere \& Daura, 2000). According to Ijere (1993), three seasons are cool dry (harmattan) season between October and March, hot dry season between April and June, and, the rainy season between July and September. Generally, temperatures are high throughout the year with hot season's ranging between $39^{\circ} \mathrm{C}-40^{\circ} \mathrm{C}$ particularly in the north. Borno south however, has a relatively mild weather especially around the Biu plateau. As observed by Ijere and Daura (2000), rainfall variability is over 100 per cent and rainy days in the north is about 80 days while it is about 140 days in the south. Two vegetation belts typical of the state are Sudan savannah and Southern Sahel in Borno south and north respectively.

Although, the state has a large land mass, it is sparsely populated. Average population density is about 37 persons per sq. km. (Borno State Statistical Yearbook, 2006). The economy is agro-based as farming households produce both for subsistence and commercial purposes. Livestock-raising is an important component of the economy. The environmental conditions such as extreme hot and cold temperature affect the health of the people hence deserved a research attention

\section{Materials and Methods}

Primary and secondary sources of data were used for the study. Primary sources comprised a range of techniques of participatory rural appraisal (PRA). Some of these have been discussed by many authors like Nel et al. (1997); Doyle and Krasny (2003); Olawepo (2003) among others. PRA being a bottom-up approach adopted is in consonance with agenda 21 of the World Commission on Environment and Development to facilitate sustainable development. Focus group discussions and Seasonal Calendars were the PRA methods employed with rural dwellers.

The questionnaire involved both close-ended and open-ended questions. The instrument was pre-tested to ensure validity and reliability. The questionnaire was used to generalize and validate information obtained through FGD. Secondary sources of data involved a systematic review of documents from government agencies and parastatals. The secondary data were used to fill the gaps that existed in the data gathered from field survey.

A multistage sampling procedure was adopted in this study. Borno state was divided into northern and southern units. Given that Borno State considers all settlements in her local government areas as rural except the local 
government headquarters, the commercial centres and the state capital (Ijere, 1993; Online Nigeria, 2003d), the rural LGAs and rural settlements were the units of observation.

Using a detailed map of the state, the local government areas of northern and southern Borno were identified. From the twenty-seven LGAs, based on the knowledge of the area under investigation, thirty percent $(30 \%)$ that is 9 LGAs were considered adequate to represent the entire population, hence, were systematically selected from the two zones. From the selected LGAs, seven (7) settlements were systematically selected to give a total of sixty three (63) settlements. Due to the small size of the selected settlements, ten households were purposively selected in each settlement regardless of the sizes and population of the settlements. The households were systematically selected such that every 5 th household head was solicited to partake in the study. This gave a total of 630 households from 63 settlements in 9 LGAs.

The quantitative analytical techniques employed were descriptive and inferential techniques. The descriptive techniques of analysis used to summarize the socio-economic and demographic characteristics of the respondents were percentages, tabulation, averages, and cross tabulation.

Z-score, a standard additive model also known as standard normal deviate was used to describe the spatial pattern of each sub-indicator of environmentally-induced deprivation in the study area while the composite score was mapped for each variable. The pictorial form ensured clarity and analytical appreciation of the pattern.

Z-score formula is of the form

$$
Z=\frac{X 1-\bar{X}}{S D}
$$

Where; $X 1$ is the original value in cell 1 ,

$\bar{X}$ is the mean for the variable,

$S D$ is the standard deviation.

As a tool for depicting spatial pattern, Z-score has been used by Smith (1972), Knox and Coltam (1981), Oyebanji (1984 and1986) and Adedayo (1988) among others with tremendous success.

\section{Analysis and Discussion of Findings}

\subsection{Socio-economic Attributes of Respondents}

Based on the socio-cultural background of the sampled population, 598 of the respondents were males, while 32 were females. The age distribution in Table 1 reveals that about $37 \%$ of the respondents fall within the age bracket of $31-50$ years while only $3.5 \%$ were between 18 and 30 years. Moreover, about $38 \%$ of the respondents were between 51-60 years while the remaining $22.1 \%$ were above 60 years of age. The age distribution indicates that majority of the respondents were adult who can contribute reasonably to health issues at the household levels. Also, Table 2 depicts the occupational characteristics of the respondents.

Table 1. Age distribution of the respondents (Source: Author's fieldwork, 2009)

\begin{tabular}{llll}
\hline Age & Frequency & $\%$ & Cumulative \% \\
\hline $18-30$ & 22 & 3.5 & 3.5 \\
$31-40$ & 65 & 10.3 & 13.8 \\
$41-50$ & 166 & 26.3 & 40.2 \\
$51-60$ & 238 & 37.8 & 77.9 \\
$60>$ & 139 & 22.1 & 100 \\
Total & 630 & 100 & 100 \\
\hline
\end{tabular}

The revelation in Table 2 is that 327 (51.91\%) of the respondent households were farming households while herders were $11.59 \%$. About $7.39 \%$ of the respondents were fisher folks while artisans such as blacksmiths, carpenters, wristwatch repairers, tailors etc were $5.08 \%$. Although, multiple occupations characterize rural livelihood, respondents were asked to state the major two occupations. In all, the following occupational combinations were identified. Farming with herding has (5.71\%), farming with fishing (6.19\%), farming with artisanal activities (3.81\%), farming and trading (4.76\%) while farming with wage employment was $3.65 \%$. The 
difference in occupations means that there exists diversity on the health burdens that people will be exposed to.

Table 2. Occupational characteristics of the respondents (Source: Author's fieldwork, 2009)

\begin{tabular}{llll}
\hline Occupation & Frequency & $\%$ & Cumulative \% \\
\hline Farming & 327 & 51.91 & 51.91 \\
Herding & 73 & 11.59 & 63.5 \\
Fishing & 46 & 7.39 & 70.8 \\
Artisanship & 32 & 5.08 & 75.88 \\
Farming \& Herding & 36 & 5.71 & 81.59 \\
Farming and Fishing & 39 & 6.19 & 87.78 \\
Farming \& Artisanship & 24 & 3.81 & 91.59 \\
Farming \& Trading & 30 & 4.76 & 96.35 \\
Farming \& Civil Service & 23 & 3.65 & 100 \\
Total & 630 & 100 & 100 \\
\hline
\end{tabular}

Educationally, 291 (46.19\%) of the respondents have not attended any form of educational institution. Another $160(25.40 \%)$ had primary education certificate; about $2.54 \%$ had tertiary education degrees and diplomas, while only $5.55 \%$ had acquired secondary education. Their household population range from four to eighteen. Expectedly, the nature of occupation requires large number of hands as labour which the family can provide. Among the respondents, 423 (67.1\%) were Muslims while 207 (32.9\%) professed Christianity.

\subsection{Deprivation Based on Spatial Pattern of Access to Health Infrastructure}

Health infrastructures are important human elements that have influence on wellbeing of people. Inaccessibility to health and medical facilities constitutes deprivation for individuals or any group of community. Apart from the general state of inadequately equipped facilities in Nigerian rural settlements, accessibility to health care facilities is usually measured in terms of physical accessibility (distance and time) and socioeconomic accessibility (affordability of services). These two components were used as indicators of health deprivation and Tables 3 and 4 present the analysis.

Table 3. Time spent to reach health facility by respondents (Source: Author's fieldwork, 2009)

\begin{tabular}{lllll}
\hline \multirow{2}{*}{ LGA } & \multicolumn{4}{l}{ Time spent by motor vehicle/motor cycle } \\
\cline { 2 - 5 } & 30 minutes & 60 minutes & 90 minutes & 120 minutes \\
\hline Bama & 10 & 23 & 22 & 21 \\
Chibok & 3 & 24 & 23 & 20 \\
Damboa & 12 & 23 & 16 & 13 \\
Hawul & 14 & 25 & 19 & 12 \\
Konduga & 13 & 28 & 17 & 12 \\
Kukawa & 4 & 26 & 30 & 10 \\
Kwaya kusar & 17 & 24 & 21 & 9 \\
Mobbar & 19 & 22 & 25 & 16 \\
Monguno & 16 & 25 & 29 & 6 \\
Total & 107 & 220 & 193 & 110 \\
Percent total & 17.0 & 34.9 & 30.6 & 17.5 \\
\hline
\end{tabular}


Table 4. Cost of obtaining health services by respondents (Source: Author's fieldwork, 2009)

\begin{tabular}{llll}
\hline Cost of service & Frequency & Percent & Cumulative \% \\
\hline $\mathrm{N}<500.00$ & 132 & 21.0 & 21.0 \\
$\mathrm{~N} 600-\mathrm{N} 1000.00$ & 250 & 39.7 & 60.6 \\
$\mathrm{~N} 1,100-\mathrm{N} 1500.00$ & 192 & 30.5 & 91.1 \\
$\mathrm{~N} 1,600-\mathrm{N} 2000.00$ & 56 & 8.9 & 100 \\
Total & 630 & 100 & 100 \\
\hline
\end{tabular}

As depicted in Table 3, a very minute population (107 equivalent to $17.0 \%$ of respondents) were within less than 30 minutes to health service which was the closest physical distance to hospitals while $220(34.9 \%)$ of rural household had to travel up to an hour before reaching a general hospital. A total of 193 (30.6\%) of respondents usually travel in a vehicle or on a motorcycle up to 90 minutes before getting medical attention while about $17.5 \%$ of the people travel up to two hours.

A spatial analysis revealed that settlements with shortest distance are in Damboa, Konduga, Monguno and Hawul LGAs. Further analysis revealed that most of the people travel up to 60 minutes before receiving medical attentions and this cut across the study area. Based on distance, settlements in Bama, Kukawa, and Mobbar have poor access. Apart from distance, the high level of poverty in rural are makes patronage difficult.

As also presented in Table 4, medical services are not free and sampled rural households paid between N500-N2000.00 (160 Naira is equivalent to 1 US Dollar) to obtain services. The table shows that $250(39.7 \%)$ of the respondents claimed to pay between N600 and N1000.00 to obtain services for mild health problems like fever, cough, stomach ailments while about 192 (30.5\%) usually spend over N1000.00. Generally, these are minor health issues because, surgery and chronic health cases that require referrals to general hospitals cost more. According to majority of the respondents, they usually spend over N20,000.00 for such serious medical services.

The revelation in Table 5 is that only 303 (48.1\%) of the respondents were within 400metre working radius to the nearest clinic/dispensary being the primary health facilities at the local level while about $327(51.9 \%)$ were beyond 400 metres radius. On the whole about, 419 (65.26\%) of the respondents suffer deprivation because of inability to patronize the facilities when situation demands. This poses a great disadvantage to the people especially when the cumulative impact of poor health conditions on income-earning, household maintenance, social stability and involvement in communal activities is considered.

Table 5. Distance to dispensary/clinic by respondents (Source: Author's fieldwork, 2009)

\begin{tabular}{lcccc}
\hline \multirow{2}{*}{ LGA } & \multicolumn{4}{c}{ Average distance to dispensaries } \\
\cline { 2 - 5 } & $160-200 \mathrm{mtrs}$ & $210-400 \mathrm{mtrs}$ & $410-600 \mathrm{mtrs}$ & $610-800 \mathrm{mtrs}$ \\
\hline Bama & 18 & 12 & 15 & 25 \\
Chibok & 8 & 24 & 18 & 20 \\
Damboa & 21 & 24 & 19 & 6 \\
Hawul & 14 & 17 & 24 & 15 \\
Konduga & 19 & 23 & 17 & 11 \\
Kukawa & 06 & 25 & 16 & 23 \\
K/Kusar & 07 & 28 & 19 & 16 \\
Mobbar & 09 & 20 & 05 & 36 \\
Monguno & 11 & 17 & 21 & 21 \\
Total & 113 & 190 & 154 & 173 \\
\% total & 17.9 & 30.2 & 24.4 & 27.5 \\
\hline
\end{tabular}

This pattern does not reflect a clear-cut distinction based on ecology. This is because some of the sub-indicators are loaded in positive direction in some areas but are in negative direction in other areas (Figure 1). Besides, 
including poor health due to environmental variables (extreme heat and cold) might have influenced the pattern of health deprivation. For instance, because of variation in high temperature in Borno north, incidence of Cerebro-spinal Meningitis, was higher among (47 households) than (19 households) in the south. The spatial pattern of health deprivation is shown in Figure 2.

As presented in pattern of health deprivation in sampled rural areas, highly deprived are settlements in Kukawa (5.11), Monguno (2.68), Kwaya Kusar (1.26) and Mobbar (1.15) LGAs. These areas cut across the two political and ecological zones although three are from Borno north. Moderately deprived are Chibok (0.68) and Bama (0.47) LGAs while relatively advantaged are Damboa (-5.94), Hawul (-2.24) and Konduga (-2.01) LGAs. This pattern revealed that areas with fairly high access to health infrastructure and have favourable weather conditions to some extent have low deprivation score and vice versa. Largely, the pattern reflects interaction of policy failure and environmental incapacity.
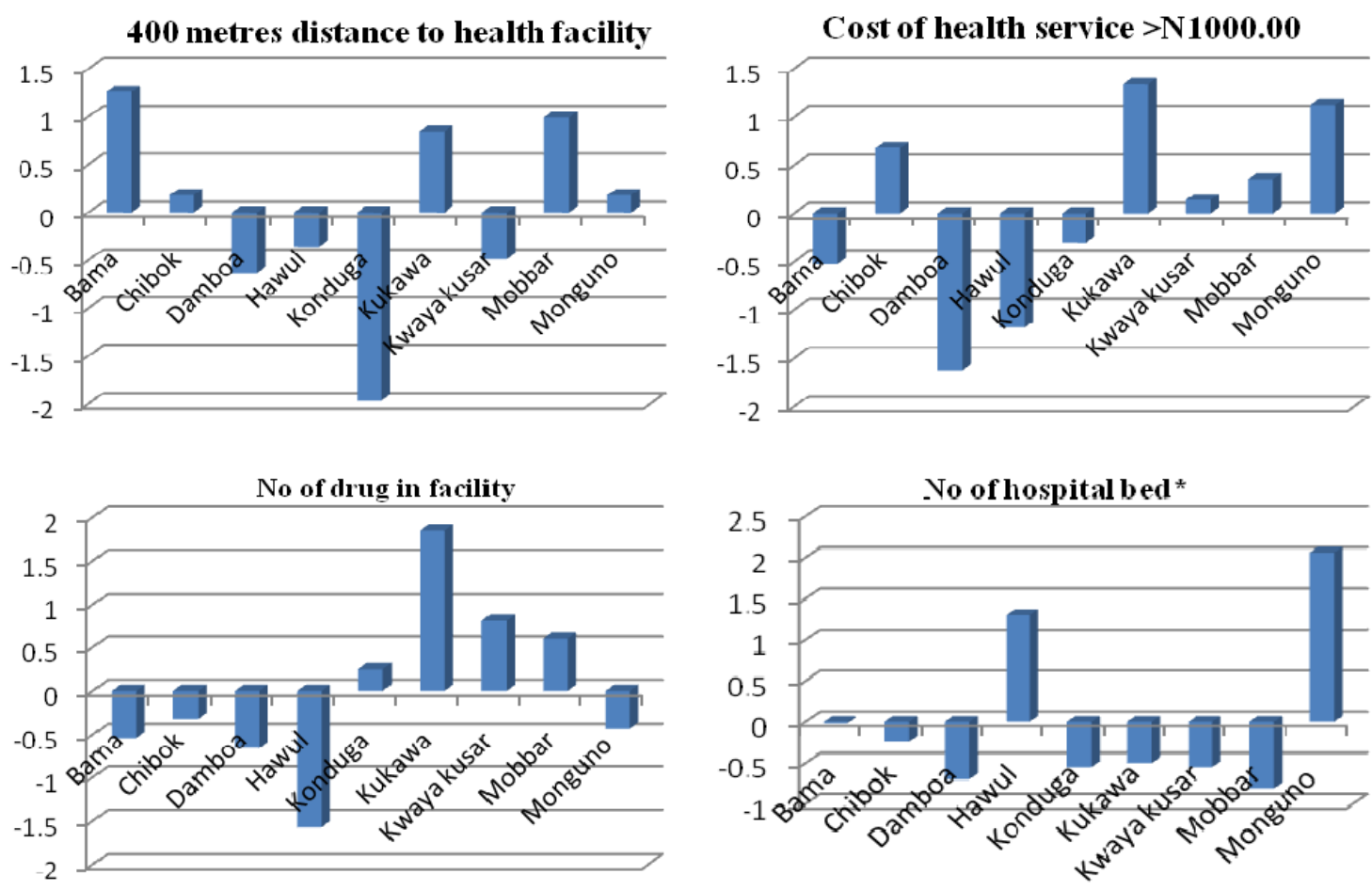

Figure 1. Divergence bar graph on sub-indicators of health deprivation

Source: Author's field survey, 2009 (*Extracted from Borno State Statistic Year Book 2005-2006) 


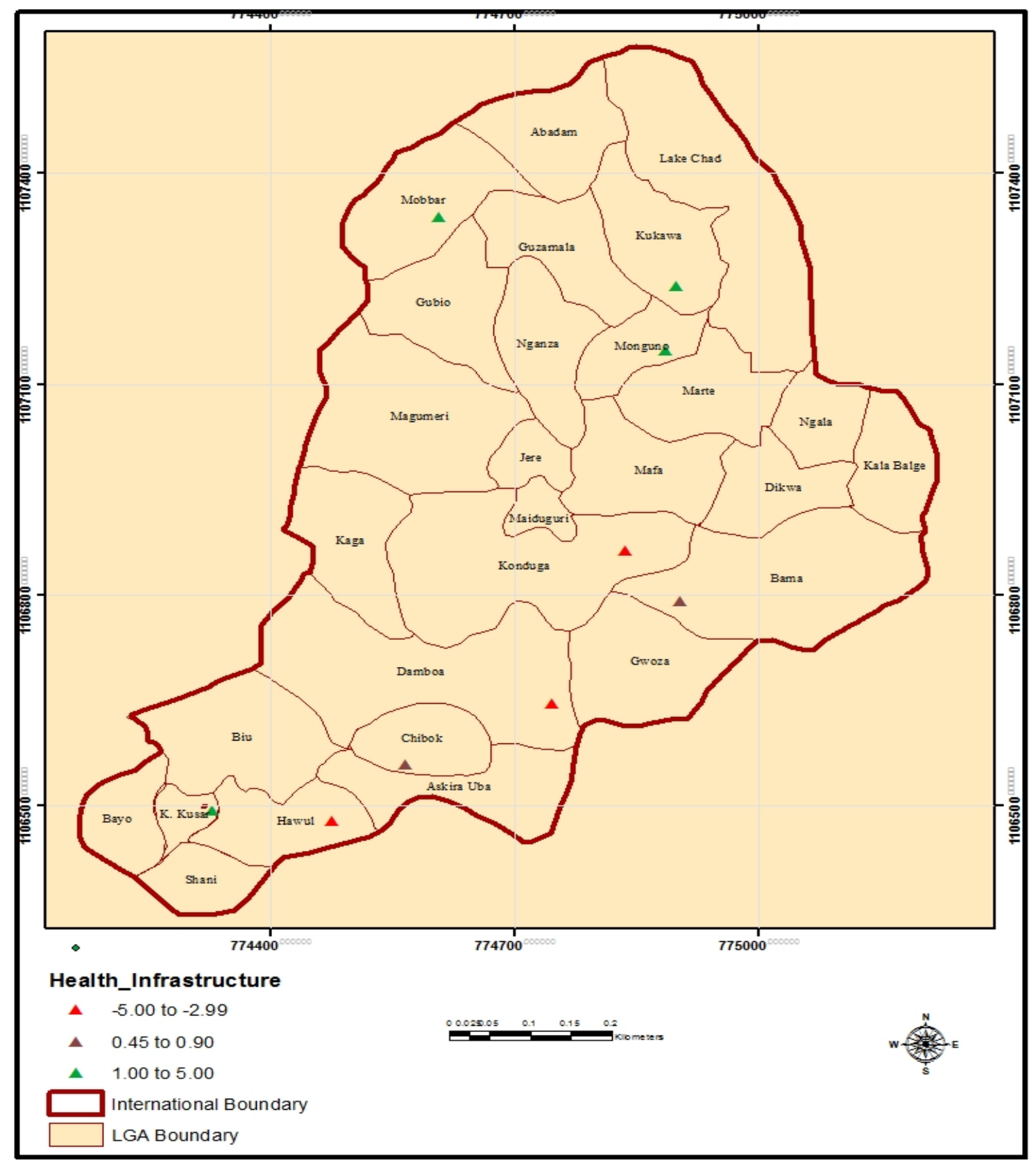

Figure 2. Spatial pattern of health deprivation in rural areas of Borno state

Source: Field survey, 2009

\subsection{Coping with Diseases and Health Deprivation}

Coping mechanisms evolved from series of social and communal interaction among rural people. Rural societies are socio-culturally homogenous and willingness to provide assistance is very high. It is from this basis coupled with the understanding of wide ranging opportunities from the environment that societal adaptive strategies have evolved.

Among the adaptive strategies to mitigate individual weakness and vulnerability are communal labour and sharing of resources. Deprivation is more pronounced in areas where emphasis is placed on individual strength. When health and medical emergency (such as surgical operations) arise, borrowing is another strategy to ameliorate income deprivation. Cash borrowing was usually to fulfill medical obligations.

Another societal adaptive strategy is seeking assistance from religious institutions. Islam and Christianity are the major religions in rural Borno State. Religious leaders know fairly well the living conditions of their members of 
congregation and are in the position to assist their members through contribution from other wealthy members. This assistance is rendered to mitigate situations like infections and health issues. Praying to God is major psychological coping strategy among rural dwellers. All the people claimed that after praying to God, their supplications are answered and their health will be restored.

As revealed in the seasonal calendar Table 6, rainy-months are about between three and four (end of August to early October in Borno north while it lasts till end of October in Borno south except for highland areas such as Biu) while dry months are more. This makes water problem to be a major environmental trigger of ill-health constraint for a better part of the year. Illnesses like fever, scabies, dysentery, CSM and others are common at peak of dryness and heat. Water cum environmentally related diseases includes water-borne transmission; water-washed transmission; water-based transmission; and water-related insect vector transmission.

Table 6. Seasonal calendar of environmental interaction with health and coping measures (Source: Author's field survey, 2009)

\begin{tabular}{|c|c|c|c|}
\hline Month & Atmospheric conditions & $\begin{array}{l}\text { Health/ environmental } \\
\text { Challenges }\end{array}$ & Coping strategies \\
\hline January & Cold-dry; Harmattan & $\begin{array}{l}\text { Diseases of livestock and } \\
\text { poultry; Pneumonia (cold \& } \\
\text { catarrh) water shortage }\end{array}$ & $\begin{array}{l}\text { Ethno-veterinary; Traditional } \\
\text { medicines, praying to God. }\end{array}$ \\
\hline February & Cold-dry; Harmattan & $\begin{array}{l}\text { Water shortage, Cold, cough, } \\
\text { catarrh, Headache }\end{array}$ & $\begin{array}{l}\text { Praying to God, Use of alternative } \\
\text { medicine, patronizing Chemists. }\end{array}$ \\
\hline March & Warm-dry & $\begin{array}{l}\text { Water scarcity, Human } \\
\text { ailments; rashes, fever, } \\
\text { body-ache }\end{array}$ & $\begin{array}{l}\text { Use of biomass resources for drugs } \\
\text { and medication. }\end{array}$ \\
\hline April & $\begin{array}{l}\text { Warm-dry; high } \\
\text { temperature }\end{array}$ & $\begin{array}{l}\text { Fever, rashes, dysentery water } \\
\text { problems, Human discomfort }\end{array}$ & $\begin{array}{l}\text { Use of biomass resources for drugs } \\
\text { and medication. }\end{array}$ \\
\hline May & $\begin{array}{l}\text { Hot-dry; very high } \\
\text { temperature }\end{array}$ & $\begin{array}{l}\text { Acute water shortage, Fever, } \\
\text { rashes, Cerebro-spinal } \\
\text { meningitis (CSM), dysentery; } \\
\text { Typhoid fever }\end{array}$ & $\begin{array}{l}\text { Government sponsored vaccination } \\
\text { and inoculation programme against } \\
\text { CSM, Self-medication, Native } \\
\text { medicine }\end{array}$ \\
\hline June & $\begin{array}{l}\text { Hot-dry; very high } \\
\text { temperature }\end{array}$ & $\begin{array}{l}\text { Acute water shortage, Malaria } \\
\& \text { Typhoid fever Malnutrition. }\end{array}$ & $\begin{array}{l}\text { Endless water-search, praying to } \\
\text { God, Herbal medicine, Migration }\end{array}$ \\
\hline July & $\begin{array}{l}\text { Hot-dry; cloudiness } \\
\text { (coolness) }\end{array}$ & $\begin{array}{l}\text { Acute water shortage, } \\
\text { Dysentery, Typhoid fever }\end{array}$ & $\begin{array}{l}\text { Water-search, praying to God, } \\
\text { Traditional medicine, Travel to city } \\
\text { for medical services. }\end{array}$ \\
\hline August & $\begin{array}{l}\text { Hot-wet cloudiness \& } \\
\text { rain shower in Southern } \\
\text { Borno }\end{array}$ & $\begin{array}{l}\text { Typhoid fever } \\
\text { *Drought condition }\end{array}$ & $\begin{array}{l}\text { Use of biomass resources for drugs } \\
\text { and medication, Alternative medical } \\
\text { therapy. }\end{array}$ \\
\hline September & $\begin{array}{l}\text { Cold-wet (in south); } \\
\text { warm-wet (in north); } \\
\text { Peak of rainfall in Borno } \\
\text { state. }\end{array}$ & $\begin{array}{l}\text { Effect of windstorm, sporadic } \\
\text { flooding in Borno south. } \\
\text { Malaria fever, Typhoid fever }\end{array}$ & $\begin{array}{l}\text { Use of biomass resources for drugs } \\
\text { and medication. Ethno-veterinary }\end{array}$ \\
\hline October & $\begin{array}{l}\text { Warm-wet; cold-wet } \\
\text { variable rainfall in north } \\
\text { and south }\end{array}$ & $\begin{array}{l}\text { Windstorm, Temperature } \\
\text { variation } \\
\text { Malaria fever, Cold \& Flu. }\end{array}$ & $\begin{array}{l}\text { Use of biomass resources for drugs } \\
\text { and medication, Alternative medical } \\
\text { therapy. }\end{array}$ \\
\hline November & $\begin{array}{l}\text { Cold-dry; On set of dry } \\
\text { season }\end{array}$ & $\begin{array}{l}\text { Water scarcity, Fever, Cold \& } \\
\text { Flu. }\end{array}$ & $\begin{array}{l}\text { Praying to God, Use of alternative } \\
\text { medicine, patronizing Chemists. }\end{array}$ \\
\hline December & Cold dry; Harmattan & $\begin{array}{l}\text { Water shortage, Fever, Cold \& } \\
\text { Flu. }\end{array}$ & $\begin{array}{l}\text { Praying to God, Use of alternative } \\
\text { medicine, patronizing Chemists, } \\
\text { Migration }\end{array}$ \\
\hline
\end{tabular}


Seasonal Calendar (Table 6) also shows that social and natural environmentally-induced health deprivation is multidimensional as experienced by rural dwellers. For all ill-health cases, lack of water and inaccessibility to qualitative health care are triggers. This made local drug stores anachronistically labeled as 'Chemists' the last resort for the fairly wealthy rural dwellers where they purchase drugs off the counter and or with injections. Among coping strategies, long and short time rural out-migration and praying to God are considered most important. Borrowing money and food from neighbours and collecting wild/biomass resources for drugs and medication are the second most important strategies. Migration is the last resort to mitigating the health (and other) disadvantages suffered by rural dwellers. Migration is a common strategy which happens seasonally or as condition demands. Travelling to urban centres for medical reasons is common.

\section{Implications of the Study, Recommendation and Conclusion}

Health deprivation is a disturbing phenomenon which hampers quality of life among respondents in sampled rural settlements of Borno State. Indeed, the studied rural communities are exposed to different disadvantages in space and time. A combination of physical and social elements of the environment induces disadvantage based on the level of accessibility or inaccessibility to them. The findings have theoretical, academic, and planning implications that can help to further the attempt at improving quality of life at the local level.

Theoretically, it corroborates previous theoretical standpoints that physical environmental elements and policy failure have a strong influence on health situations of rural dwellers. Besides, the participatory analysis shows that, outsiders can learn from indigenous knowledge towards contributing to contemporary knowledge on survival strategies in rural settlements. This study reveals that spatial disparity in manifestation of environmentally-induced deprivation reflects the physical environmental and human (social/policy) factors operational at any point in time. In this study, the revelation of spatio-temporal disparity is between and within settlements located in Borno North and Borno South ecological divisions.

Certainly, these areas where deprivation manifests urgently deserve comprehensive positive discrimination policies that could reduce both inter spatial (Borno-north versus Borno south) and intra-spatial (within rural community) deprivation experienced by the people. A study like this demonstrates the pivotal roles that rural geographers working within a social and physical environmental framework play in reducing deprivation at local and regional levels towards contributing to overall national development. The identification of areas that suffer which type of health deprivation is a pointer to areas where serious efforts should be directed. Certainly, these warrant policy recommendations.

Provision of health facilities in the sampled rural areas will help in improving the quality of life. At least, providing a primary health care ( $\mathrm{PHC}$ ) centre to service two proximate communities will reduce the distance rural dwellers cover to access health care. Also, several communities studied lack access to adequate potable water hence, the incidence of water-borne and water-washed diseases. Provision of expertise on water resources management (such rain water harvesting) will reduce some of the communicable diseases.

Government should create a healthy environment for mainstream non-government organizations (NGOs), environmental non-government organizations (ENGOs) and community based organizations (CBOs) and other advocacy groups to partner with rural people in health management. This will go a long way in supporting the institutional strategies used in mitigating deprivation.

There is also the need to encourage self-help activities among the rural dwellers. Policy failure is a strong indication that government cannot provide all the resources that mitigate health deprivation at the local level. Self-help activities in conjunction with home town development associations make it realistic that financial resources in urban and rural areas are jointly mobilized to build health infrastructure. Many rural communities in southern part of Nigeria have actually used self-help efforts to provide infrastructures such as road, schools, electricity, potable water and educational institutions for their communities.

\section{References}

Adedayo, A. (1988a). Citizen Participation in Community Development Planning and Imple mentation at the Local Level. Ilorin Journal of Business and Social Science, 6(2), 27-38.

Adedayo, A. (1988b). Spatial Ecology of Social Deprivation in a Rural Nigerian Environment. International Journal of Environmental Studies, 31(1), 45-53. http://dx.doi.org/10.1080/00207238508710412

Adedayo, A. (2003). Irrigation and Rural Welfare: Implication of Schistosomiasis Among Farmers in Kazaure LGA, Jigawa State Nigeria. Journal of Agriculture, Resources and Development, 2, 52-59. 
Ademola, A. (1997). A Sociological Analysis of the Role of Traditional Medicine in Health -Care Delivery in Rural Community: A Case Study of a Traditional Bone Setting Clinic in Iyamoye, Kogi- State, Nigeria. Ife Social Science Review, 14(1\&2), 62-70.

African Development Report. (2002). Rural Development for Poverty Reduction in Nigeria. Summary of African Development Report. African Development Bank.

Akpovi, S. U. (2002). Management Problems of Rural Health Care Programmes: A Case Study of Idere Community. Benin Journal of Social Sciences, 10, 11-21.

Borno State. (2006). Statistical Year Book of Borno State, Department of Budget. Planning Statistics Directorate. Maiduguri

Castro-leal, F., Daton, J., Demery, L., \& Mehra, K. (1999). Public Social Spending in Africa, Do the Poor Benefit? The World Bank Research Observer, 14(1), 49-72. http://dx.doi.org/10.1093/wbro/14.1.49

Doyle, R., \& Krasny, M. (2003). PRA as an Approach to Environmental Education in Urban Community Gardens. Environmental Education Research, 1, 91-115. http://dx.doi.org/10.1080/13504620303464

Human Development Report (HDR). (2004). HIV and Aids: A Challenge to Sustainable Human Development. Nigeria/ World Bank.

Ijere, J. A. (1993). Borno State. in Udo, R. K., \& Mamman, A. B. (eds) Nigeria: Giant in the Tropics, Lagos Gabumo Publishing Company, 2, 111-116.

Ijere, J. A., \& Daura, M. M. (2000). Borno State, In Mamman, A. B., Oyebanji, J. O., \& Peters, S. W. (eds) Nigeria: A People United, A Future Assured. Vol. 2. Millennium Edition. Calabar. Gabumo Publishing Company, 103-120.

Kerbo, R. H. (2000). Social Stratification and Inequality: Class Conflict in Historical Comparative and Global Perspective ( $4^{\text {th }}$ ed.). Mc Graw Hill.

Knox, P., \& Coltam, B. (1981). Rural Deprivation in Scotland. A Preliminary Assessment. TESG, 72(3), $162-175$.

Millennium Ecosystem Assessment (MEA). (2006). Ecosystems and Human Wellbeing: A Framework for Assessment. Washington. D.C: Island Press.

Murphy, E. M. (2005). Health Bulletin. No.2. Population References Bureau

Nel, E., Binns, T., \& Hill, T. (1997). Learning from the People. PRA, Geography and Rural Development in the 'new" South Africa. Applied Geography, 17(1), 1-9.

Nigeria Federal Government. (2007). Federal Republic of Nigeria, Official Gazette Vol. 94, No 24. Lagos: Government Printer.

Nwaiwu, N. E., \& Okuofu, C. A. (2004). Rural Household Hygiene in Borno State. Nigeria. Attitudes and Perception. International Journal of Gender and Health Studies, 2(1\&2), 86-95.

Olawepo, R. A. (2003). Managing the Nigerian Rural Environment for Sustainable Development through Participatory Rural Appraisal. Ilorin Journal of Business and Social Sciences, 8(1\&2), 32-39.

Omudu, E. A. \& Onah, J. (2002). Rapid Assessment Method for Community Diagnosis of Onchocerciasis: Preliminary findings from Okpokwu and Apa LGAs of Benue state Nigeria. The Benue Valley, 1(1), 34-38.

On line Nigeria. (2003). Nigeria: Borno State on-line. Retrieved June 13, 2007, from http://www.onlinenigeria.com// links/boron-adv.asp

Oyebanji, J. O. (1984). Multiple Deprivation in Cities. The case of Ilorin, Nigeria. Applied Geography, 4, 71-80. http://dx.doi.org/10.1016/0143-6228(84)90006-7

Oyebanji, J. O. (1986). Coat of Many Colours. An inaugural Lecture delivered at the University of Ilorin, Ilorin, on November 11, 1986.

Smith, D. M. (1972). Geography and Social Indicators. South Africa Geographical Journal, 54, 43-57.

United Nations System in Nigeria. (2001). Common Country Assessment, March, 2001 